\title{
Smoke Dispersion Simulations for Prescribed Burns at Site 300, Lawrence Livermore National Laboratory
}

M.M. Bradley, F.J. Aluzzi, P.J. Vogt, C.H. Hall, L.A. Neher, L.A. Wilder

\section{April 4, 2002}

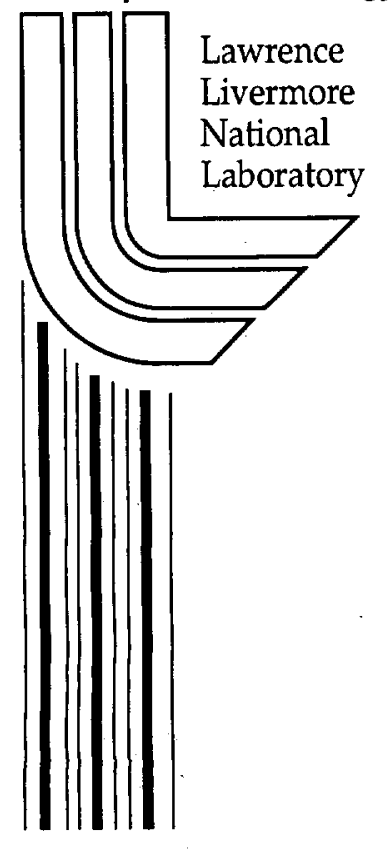




\section{DISCLAIMER}

This document was prepared as an account of work sponsored by an agency of the United States Government. Neither the United States Government nor the University of California nor any of their employees, makes any warranty, express or implied, or assumes any legal liability or responsibility for the accuracy, completeness, or usefulness of any information, apparatus, product, or process disclosed, or represents that its use would not infringe privately owned rights. Reference herein to any specific commercial product, process, or service by trade name, trademark, manufacturer, or otherwise, does not necessarily constitute or imply its endorsement, recommendation, or favoring by the United States Government or the University of California. The views and opinions of authors expressed herein do not necessarily state or reflect those of the United States Government or the University of California, and shall not be used for advertising or product endorsement purposes.

This work was performed under the auspices of the U.S. Department of Energy by the University of California, Lawrence Livermore National Laboratory under Contract No. W-7405-Eng-48.

This report has been reproduced directly from the best available copy.

Available electronically at http://www.doe.gov/bridge

Available for a processing fee to U.S. Department of Energy

and its contractors in paper from

U.S. Department of Energy

Office of Scientific and Technical Information

P.O. Box 62

Oak Ridge, TN 37831-0062

Telephone: (865) 576-8401

Facsimile: (865) 576-5728

E-mail: reports@adonis.osti.gov

Available for the sale to the public from

U.S. Department of Commerce

National Technical Information Service 5285 Port Royal Road Springfield, VA 22161

Telephone: (800) 553-6847

Facsimile: (703) 605-6900

E-mail: orders@ntis.fedworld.gov

Online ordering: http://www.ntis.gov/ordering.htm

OR

Lawrence Livermore National Laboratory

Technical Information Department's Digital Library

http://www.llnl.gov/tid/Library.html 


\title{
Smoke Dispersion Simulations for Prescribed Burns at Site 300, Lawrence Livermore National Laboratory
}

\author{
Michael M. Bradley', Fernando J. Aluzzi, and Philip J. Vogt \\ National Atmospheric Release Advisory Center (NARAC) \\ Charles H. Hall, Lee A. Neher, Lynn A. Wilder \\ GIS Center, Health and Ecological Assessment Division \\ Lawrence Livermore National Laboratory \\ Livermore, CA 94551
}

\section{INTRODUCTION}

Each year, as part of its ongoing commitment to safe operating practices, Lawrence Livermore National Laboratory (LLNL) conducts prescribed burns at its Site 300 complex. LLNL consistently adheres to stringent, self-imposed safety standards in all of its activities, and the annual prescribed burning at Site 300 is done to prevent an accumulation of vegetative fuels (primarily grasses) that could cause an unacceptable risk of wildfire ignition. The LLNL prescribed burn procedure (Burklin, 2001) calls for the sequential, controlled burning of individual small land plots by the LLNL Fire Department. Essentially the same burning procedure is repeated on a yearly basis. The burns usually are conducted in May and June; however, on rare occasions the burning has been done as late in the year as July.

To the best of our knowledge there has never been an environmental problem caused by the smoke from these prescribed burns. Indeed, the avoidance of undesirable environmental impacts is inherent in the very concept of prescription burning. In order to better understand, in a quantitative sense, the atmospheric dispersion of smoke from prescribed burns at Site 300 , and to examine how smoke behavior might differ for different burn months and burn-plot terrain, the National Atmospheric Release Advisory Center ${ }^{2}$ (NARAC) at LLNL has simulated the smoke dispersion from eight prescribed burns. Four of these burns were conducted on two days in June 1999 , and the other four burns were conducted on two days in July 2000 . This report describes the atmospheric models, fuel data, and atmospheric data used in the case studies. It also describes the GIS-based analysis of the simulations, and summarizes the simulation results.

\section{DESCRIPTION OF THE SITE 300 BURN AREAS}

Site 300 is located in the California Coastal Range, which is characterized by low, rugged mountains and relatively narrow intervening valleys. The site is situated 15 miles east of the Livermore Valley, near the eastern edge of the Altamont Hills and close to the western boundary of San Joaquin County (Figure 1). Elevations range from 500 feet at the southern boundary to

\footnotetext{
${ }^{1}$ Principal author contact information: phone 925-422-1835, e-mail mbradley@llnl.gov

${ }^{2}$ The NARAC web site is located at http://narac.llnl.gov
} 
1800 feet at the higher peaks in the northwestern areas. Site 300 covers approximately 7000 acres (about 11 square miles) of land in eastern Alameda County and western San Joaquin County. The site was acquired in 1953; since then all grazing and other agricultural activities have been terminated.

The 1,500-acre control burn area is divided into 22 plots ranging from 6 to 240 acres (Figure 2). The fuel load within the control burn plots ranges between one to four tons per acre, depending on the grass height and distribution. Existing service roads, fire trails, and other barriers separate the plots. Wet-line firing methods and temporary control lines are also used to establish plot boundaries.

\section{THE NARAC MODELING SYSTEM}

NARAC meteorologists use a suite of advanced three-dimensional models to simulate the transport and diffusion of almost any material that could be released into the atmosphere. Because of the vertical sheers of speed and direction that characterize typical airflows over the Sacramento and San Joaquin Valleys, and because the smoke from prescribed burns rises through these sheared layers, a three-dimensional modeling capability such as NARAC is essential for this case study.

The NARAC model equations are formulated in terrain-following coordinates, which facilitate more accurate simulations of atmospheric dispersion over complex terrain than would be possible with Cartesian coordinates. The equations are solved on three-dimensional grids that are uniquely created for each specific locale, using data from NARAC's worldwide, 0.5-kilometerresolution, terrain-elevation database.

The NARAC's meteorological data assimilation model, ADAPT, interpolates and adjusts atmospheric observations and forecasts to produce gridded, three-dimensional data fields describing the atmospheric conditions over specific areas of interest (e.g., the vicinity of Site 300). ADAPT constructs fields of such variables as the mean winds, pressure, precipitation, temperature, and turbulence, using a variety of interpolation methods and atmospheric parameterizations (Sugiyama and Chan, 1998). Non-divergent wind fields are produced by an adjustment procedure based on the variational principle and a finite-element discretization.

The atmospheric transport and turbulent diffusion processes are simulated with NARAC's LODI model, which uses the gridded atmospheric data produced by ADAPT and thousands of numerical "marker particles" to represent the dispersing material. LODI, solves the 3-D advection-diffusion equation using a Lagrangian stochastic, Monte Carlo method (Nasstrom et al., 2000; Ermak and Nasstrom, 2000). LODI includes methods for simulating the processes of mean wind advection, turbulent diffusion, radioactive decay and production, bio-agent degradation, first-order chemical reactions, wet deposition, gravitational settling, dry deposition, and buoyant/momentum plume rise. As time passes during a LODI simulation, the marker particles are transported by the wind and diffused by turbulence within a virtual atmosphere in the NARAC computers. The resulting three-dimensional concentration patterns are analyzed at user-defined times (for example, hourly), using a suite of post-processing tools, and graphical 
representations of concentration, dose, and/or health effects are produced to fulfill specific customer requirements.

NARAC's modeling capability is supported by vast quantities of meteorological data that NARAC constantly collects from around the world. Observational data are collected at least hourly for surface stations and twice daily for the upper atmosphere. Three-dimensional, gridded atmospheric analyses and forecast data are provided to NARAC by the U.S. Air Force Weather Agency, the U.S. Navy Fleet Numerical Meteorological and Oceanographic Center, and the National Weather Service. The NARAC modeling system also includes an in-house version of the Naval Research Laboratory s mesoscale weather forecast model, COAMPS (Coupled OceanAtmosphere Mesoscale Prediction System, Hodur, 1997). The COAMPS model is based on nonhydrostatic compressible dynamics, and includes parameterizations for subgrid-scale mixing, explicit moist physics, cumulus convection, and radiation. This case study used a combination of weather data from several sources, including observational data collected and archived by NARAC, and COAMPS atmospheric simulations run by NARAC (see subsequent section entitled METEOROLOGICAL DATA).

\section{VEGETATIVE FUEL AND PARTICULATE EMISSION DATA}

The NARAC models require descriptive information on the source of an atmospheric release (in this case the prescribed burn), including its location, start and stop time, type of material being released, quantity of material released, and geometry of the source. Ralph Burklin, the LLNL Assistant Fire Chief, provided us with information on the specific plots that were burned (source location), the time of ignition and duration of the burns (source start and stop time), the type of vegetative fuel, (material being released), and the plume heights above the terrain (source geometry). The vegetative fuel for Site 300 is almost entirely composed of ungrazed native and introduced grasses. Chief Burklin also provided information on the area of each burn plot, the vegetative fuel loading (mass of fuel per surface area), and an estimate of the percent of the fuel that was consumed by the prescribed burns. Using this information and a smoke mass emission factor calculated from information on the California Air Resources Board web site, we were able to estimate the smoke PM10 emission rate for each of the burns. A summary of the smoke source data is provided in Table 1.

The smoke sources were represented in the LODI model as plumes of PM10 particles rising from circular source areas on the ground. These circular areas were centered on the centroids of the irregularly shaped actual burn plots, and their radii were chosen such that the circles' areas equaled the areas of the actual burn plots they represented. The plume rise heights for each simulation were set to correspond to the observed plume heights reported by Chief Burklin.

\section{METEOROLOGICAL DATA}

Because the meteorological data used for the dispersion calculations were chosen to be the best that were available for each of the two years, different blends of data sources were used for the 1999 and 2000 simulations. Figures 3 and 4 show sample plots of the surface and midatmospheric-level wind data used in the calculations for 1999 and 2000. 
Data for the 1999 Cases

NARAC used the COAMPS model to generate hourly regional wind fields for the 1999 cases. Although COAMPS is generally regarded as a weather prediction model, NARAC has used it successfully on several occasions in a forensic mode, i.e. to recreate relatively high-spatialresolution atmospheric data from relatively coarse-resolution, historic data. The resolution of the innermost COAMPS nest used for this study was $12 \mathrm{~km}$. The COAMPS model was initialized using archived data from the NOGAPS (Navy Operational Global Atmosphere Prediction system) weather prediction model, which produces wind data at $1 ;$ resolution over the entire globe. In addition to the COAMPS-simulated data, we also used 15-minute-interval observational data from the Site-300 meteorological tower. The tower observations were given enhanced weighting (in the ADAPT diagnostic model) to preserve the detailed temporal information provided by these more frequent observations.

\section{Data for 2000 Cases}

NARAC used regional hourly-observed weather for the 2000 cases. As for the 1999 cases, the Site-300 15-minute tower data also were included. We also used two nearby profilers (located in west Livermore and in Tracy) for detailed upper air wind observations. The profilers provided hourly wind observations with a vertical resolution of 65 meters from the surface up to approximately three kilometers of altitude. Because of the availability of the profiler data, and based on our meteorological experience, we decided that it was not necessary to use forensic COAMPS data for the 2000 cases.

\section{GIS ANALYSES OF NARAC SIMULATIONS}

A GIS team that was independent of the modeling team conducted the analyses of the smoke dispersion simulations. Consistencies of the independent analyses with the physics-based expectations of the meteorologist-modelers tended to increase our confidence in the accuracy of the results.

The NARAC LODI model results were contoured by average-hourly concentration values, and then converted to hourly time-sequenced polygons using a combination of ArcInfo software with scripts (written in AML -- Arc Macro Language) to automate the plume graphics production process. The data were converted to a vector data storage format that stores location, shape and attribute information about geographic features.

The individual plumes were then imported into ArcMap software and draped over a Landsat TM (Thematic Map) mosaic of California with 1.0 arc-second pixel resolution. The sensitive receptor data were provided by Powerfinder software, which is equivalent to a digital phone book. The software was queried by SIC (Standard Industrial Classification) to locate all sensitive receptors i.e. nursing homes, schools, hospitals, and daycare centers/providers within a 25 -mile radius of Site 300. The point data were plotted over the Landsat base map. We used additional data sets to obtain information on streets (major and minor), urbanized areas, and county boundaries. The icons used to designate sensitive receptors in the GIS analyses (Figures $6 \mathrm{~b}, 7 \mathrm{~b}, 8 \mathrm{~b}$, and $9 \mathrm{~b}$ ) are shown in Figure 5. 


\section{SIMULATION RESULTS}

The simulation results are shown in Figures 6 -9. For each burn date studied, the first figure (Figure a) shows the geometry and location of the prescribed burn plot, and the second figure (Figure b) shows contours' of the calculated 24-hour-average PM10 smoke concentration at breathing level (defined as $1.5 \mathrm{~m}$ above the terrain). Animations of sequential, hourly-averaged PM10 smoke concentrations are also available in a PowerPoint presentation developed by the GIS team.

$\underline{\text { June } 4,1999}$

For the June 4, 1999 case, the NARAC models used COAMPS-simulated atmospheric data, blended with 15-minute-interval observations from the Site 300 meteorological tower. The burn area is shown in Figure 6a, and the simulated 24-hour-average PM10 concentrations are shown in Figure $6 \mathrm{~b}$. Notice that the $50-\mathrm{g} / \mathrm{m}^{3}$ contour is restricted to the immediate vicinity of the fire (in the center of the Site 300 complex). The $5.0-\mathrm{g} / \mathrm{m}^{3}$ contour extends only about three miles beyond the site boundary, over an unpopulated area of rugged terrain. The $\left\{5.0 \mathrm{~g} / \mathrm{m}^{3}>\right.$ PM10 concentration $\left.\ddagger 0.5 \mathrm{~g} / \mathrm{m}^{3}\right\}$ region extends approximately 20 miles to the east-southeast of Site 300 , but does not overlap any sensitive receptors or population centers.

June 10,1999

We simulated the smoke dispersion from each of the three prescribed burns on June 10,1999. As for the June 4 case, we used COAMPS-simulated atmospheric data, blended with 15-minuteinterval observations from the Site- 300 meteorological tower. The total area burned is shown in Figure 7a, and the simulated 24-hour-average PM10 concentrations, summed for all three burns, are shown in Figure $7 \mathrm{~b}$. As was the case for the June 4 burn, the $50-\mathrm{g} / \mathrm{m}^{3}$ contour is restricted to the immediate vicinity of the fire (in the center of the Site 300 complex). Notice, also, that the areas within the $5.0-\mathrm{g} / \mathrm{m}^{3}$ contours are located primarily over higher terrain elevations downwind (southeast) from the fire. This is because the contours are evaluated at a constant 1.5 -meter height above the terrain, and the higher terrain features protrude up into the elevated smoke plume. Similarly, the "hole" in the $0.5 \mathrm{~g} / \mathrm{m}^{3}$-contoured region above Puerto Canyon Road occurs because the canyon floor lies beneath that concentration level in the elevated plume. Note that the average PM10 concentrations within most of the shaded area have values between 10 and 100 times less than the maximum allowable ${ }^{3}$ value.

$\underline{\text { July } 18,2000}$

We also simulated each of the three burns on July 18, 2000. The NARAC models used atmospheric data from surface stations, two profilers, and the Site 300 meteorological tower. The total area burned is shown in Figure 8a, and the 24-hour-average PM10 concentrations, summed for all three burns, are shown in Figure 8b. Once again, the simulated concentrations are all well below the maximum allowable value, except for a small area on Site 300 , in the immediate vicinity of the burn. The area of contoured 24-hour-average smoke concentration is rather narrow, and is restricted to a sparsely populated area of rugged terrain to the south-southeast of Site 300. A comparison of Figures $8 \mathrm{~b}$ and $7 \mathrm{~b}$ illustrates how differing atmospheric conditions can change the smoke dispersion patterns from otherwise very similar prescribed burns.

\footnotetext{
${ }^{3}$ The California Air Resources Board standard for 24-hour-average PM10 is $50 \mathrm{~g} / \mathrm{m}^{3}$.
} 
July 20,2000

On July 20, 2000, the burn area was located in south-central portion of Site 300 (see Figure 9a). As for the July 18 case, the NARAC models used atmospheric data from surface stations, two profilers, and the Site 300 meteorological tower. Once again, the simulated 24-hour average smoke concentration contours are rather narrow, and remain completely over the sparsely populated, rugged terrain to the south-southeast of Site 300 (see Figure $9 \mathrm{~b}$ ). The simulated offsite 24-hour-average PM10 concentrations do not exceed $0.5 \mathrm{~g} / \mathrm{m}^{3}$ except for right along the southern boundary of Site 300 , where they are approximately $5.0 \mathrm{~g} / \mathrm{m}^{3}$.

\section{SUMMARY AND CONCLUSIONS}

In this case study we simulated the atmospheric dispersion of PM10 smoke particles from eight prescribed burns at LLNL Site 300. The study included simulations for four prescribed burns in 1999, and four burns in 2000. An important result of the study is that the simulated offsite 24-hour-average PM10 smoke concentrations did not exceed the maximum allowable value of $50^{\circ} \mathrm{g} / \mathrm{m}^{3}$ for any of the cases studied, even on the two occasions when three burns were accomplished on a single day. Only relatively small geographical areas experienced 24-houraverage concentrations in excess of $5.0 \mathrm{~g} / \mathrm{m}^{3}$ (10\% of the maximum allowable value). Except for the Carneige Recreational Vehicle (RV) Park, adjacent to Site 300 (and only for the July 2000 burns), no sensitive receptors were located within the $5.0 \mathrm{~g} / \mathrm{m}^{3}$ contour. Even when the average concentrations are contoured at $0.5 \mathrm{~g} / \mathrm{m}^{3}$ ( $1 \%$ of the maximum allowable value), no sensitive receptors lie within the contoured areas in 1999, and only the RV park was within the contoured area in 2000 . In no case did the simulated smoke plume drift over a population center.

Considerably more simulations would be required to discern any climatological differences in the smoke dispersion patterns for June and July. It also must be noted that LLNL only conducts burns on days for which the weather conditions "fall within the prescription". Obviously, this selective process precludes developing a smoke dispersion climatology based solely on simulations for actual burn days. With those caveats in mind we note that, for the very limited sampling of four case days in this study, the simulated near-surface plume centerlines for the June 1999 cases extend generally southeastward from the burn sites, while they extend more nearly south-southeasterly for the two July 2000 cases. Of course, additional factors, such as the seasonal dependence of fuel moisture content and operational considerations at Site 300, must also be taken into account when scheduling prescribed burns.

This study provides persuasive evidence that there were no air quality problems caused by the eight prescribed burns for which we simulated smoke dispersion. In addition, the study confirms that combining the capabilities of NARAC with advanced GIS techniques provides a powerful, scientifically based decision-making tool for evaluating the atmospheric dispersion of smoke from prescribed burns. The same tools used for this forensic study could also be used in a predictive mode to provide reliable estimates of expected smoke dispersion at least 24 hours before prescribed burns are ignited. 


\section{REFERENCES}

Burklin, R.W., 2001: Site 300 Explosive Test Facility Prescribed Fire Plan, Lawrence Livermore National Laboratory (available from LLNL Fire Department).

Ermak, D.L., and J.S. Nasstrom, 2000: A Lagrangian Stochastic Diffusion Method for Inhomogeneous Turbulence, Atmos. Environ., 34, 7, 1059-1068.

Hodur, R. M., 1997: The Navel Research Laboratory s Coupled Ocean/Atmosphere Mesoscale Prediction System (COAMPS), Mon. Wea. Rev., 125, 1414-1430

Nasstrom, J.S., G. Sugiyama, J.M. Leone, Jr., and D.L. Ermak, 2000: A real-time atmospheric dispersion modeling system, Preprint, Eleventh Joint Conference on the Applications of Air Pollution Meteorology, Long Beach, CA, Jan. 9-14, 2000. American Meteorological Society, Boston, MA.

Sugiyama, G. and S. T. Chan, 1998: A New Meteorological Data Assimilation Model for Real-Time Emergency Response, Preprint, 10th Joint Conference on the Applications of Air Pollution

Meteorology, Phoenix, AZ (11-16 January, 1998), Am. Met. Soc., Boston, MA. 285-289. 

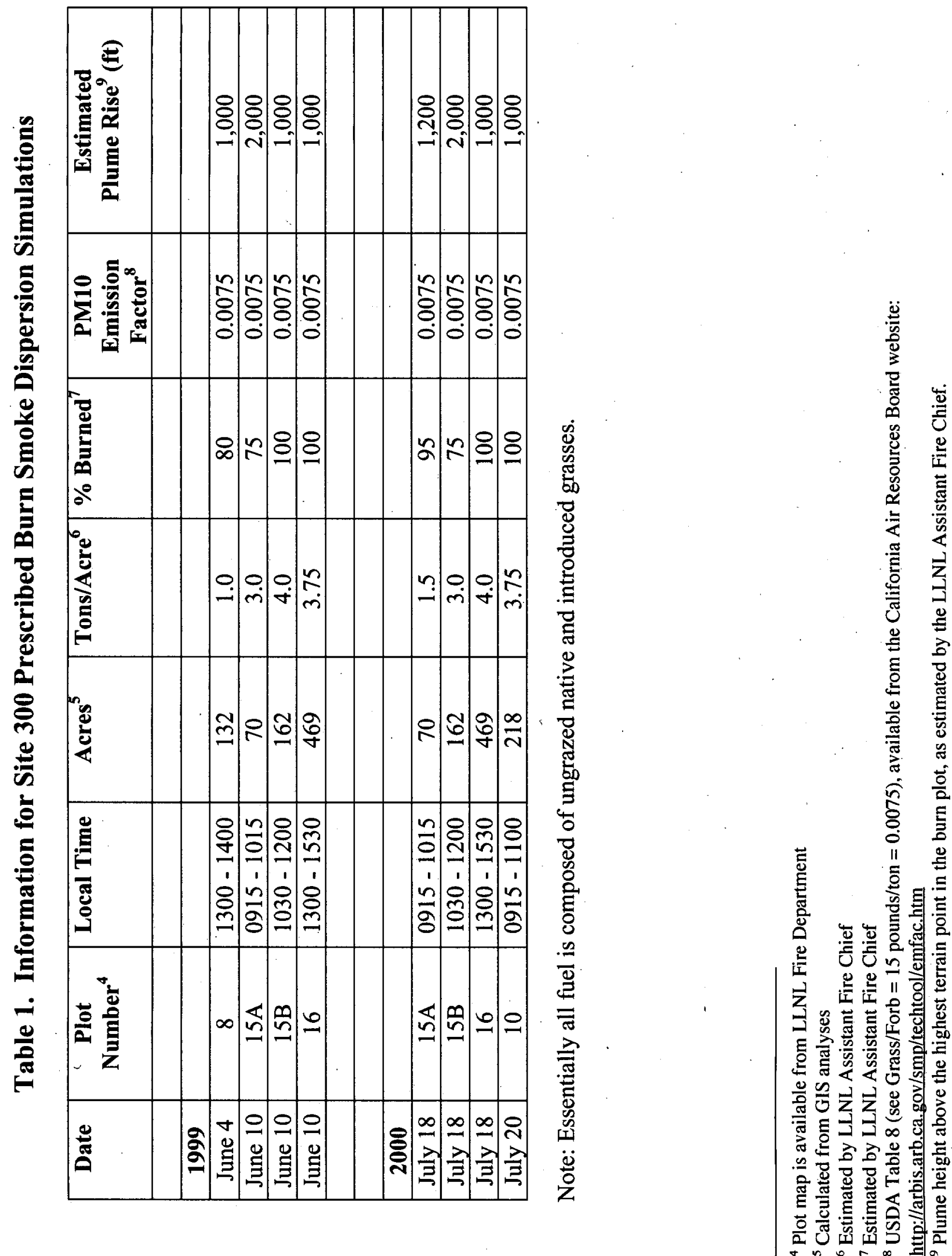

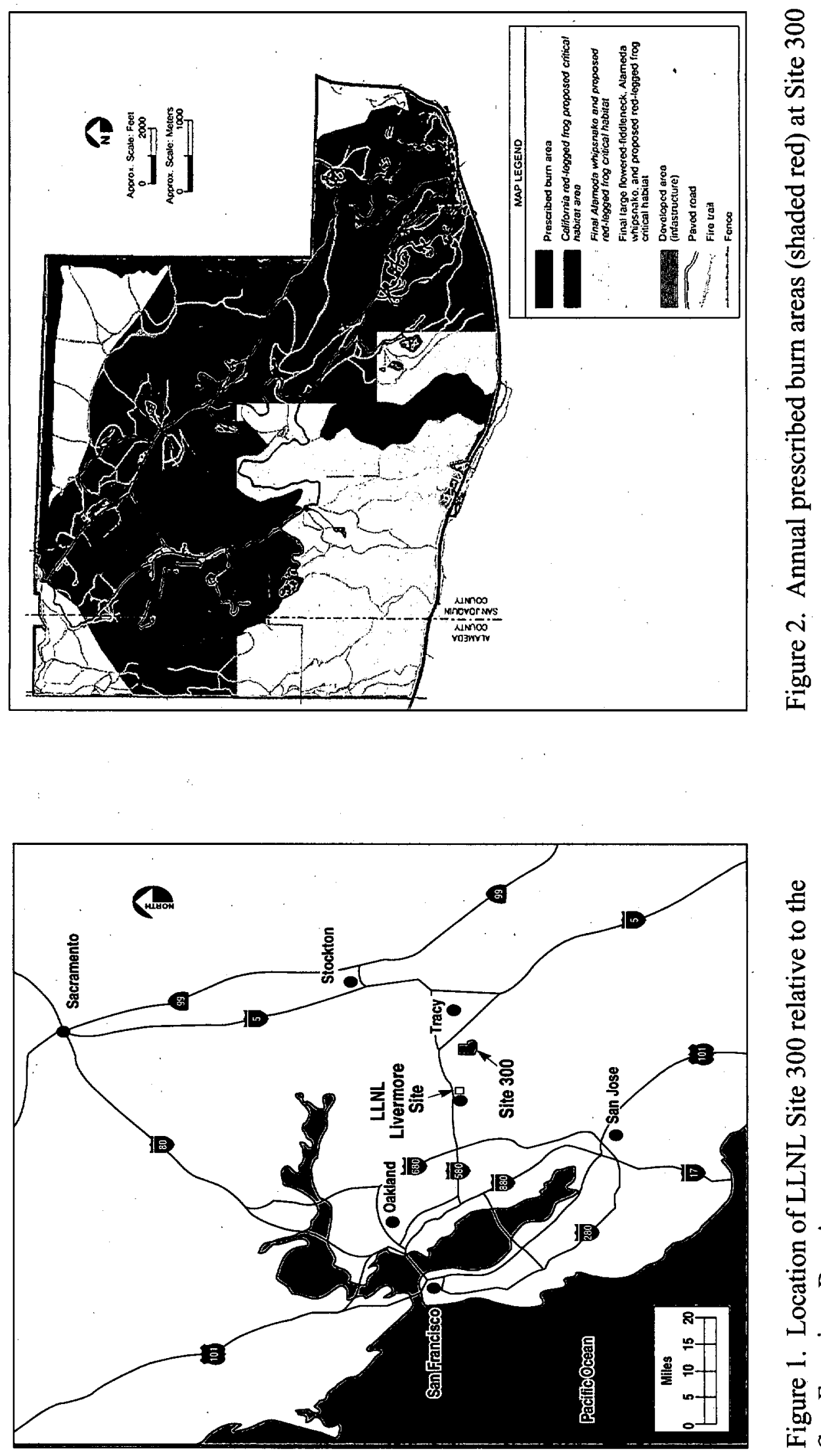

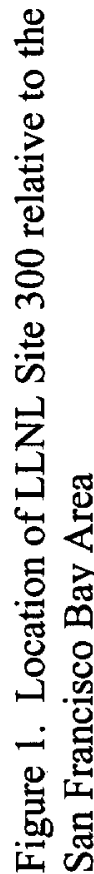



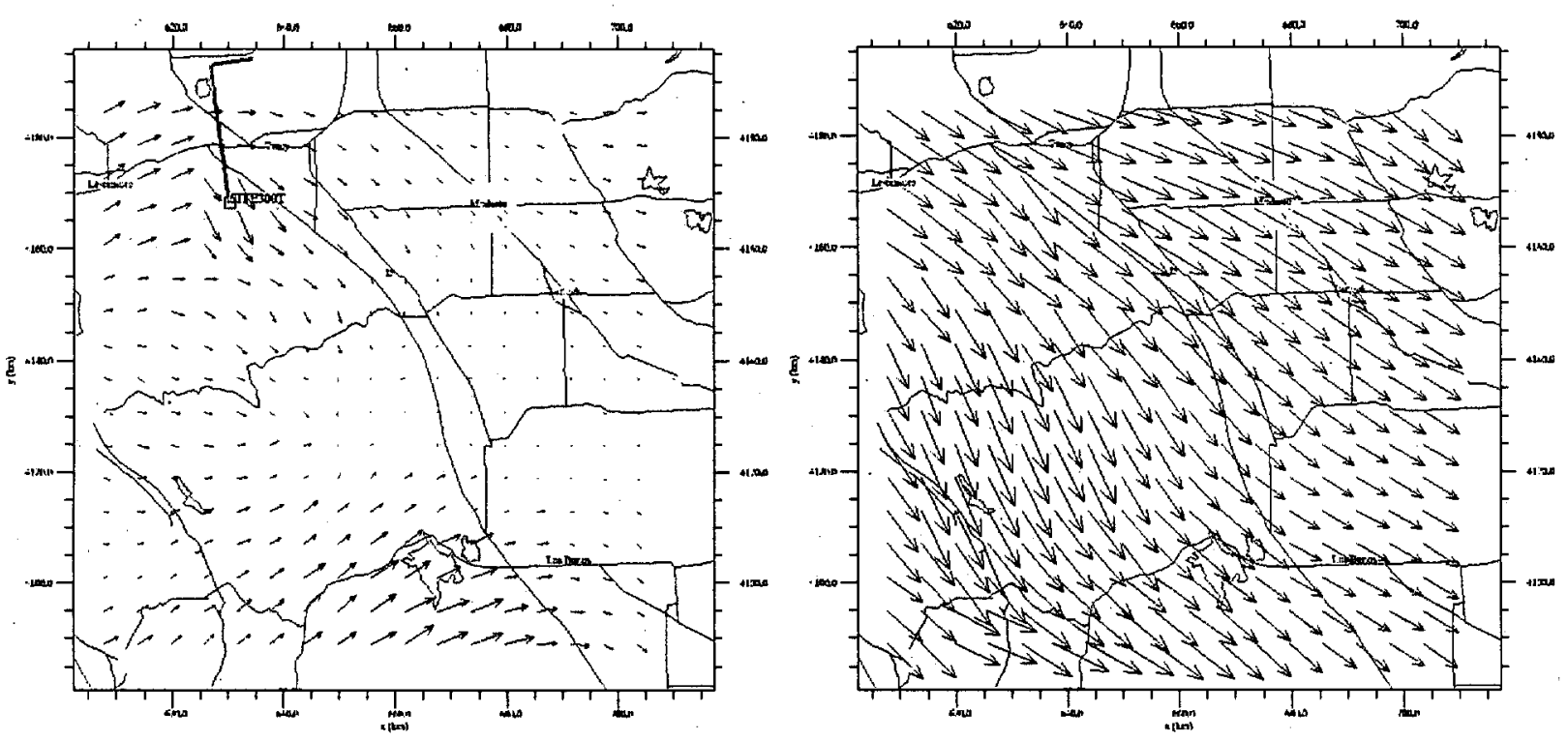

Figure 3. The blue arrows represent the near-surface wind field (left panel) and mid-level (approximately $1500 \mathrm{~m}$ AGL) wind field (right panel) from the ADAPT model for $1715^{\circ} \mathrm{UTC}(1015$ a.m. PDT) 4 June 1999. These ADAPT wind fields are based on COAMPS simulations and meteorological tower data (see text). The purple wind barb represents the Site 300 tower wind observation.
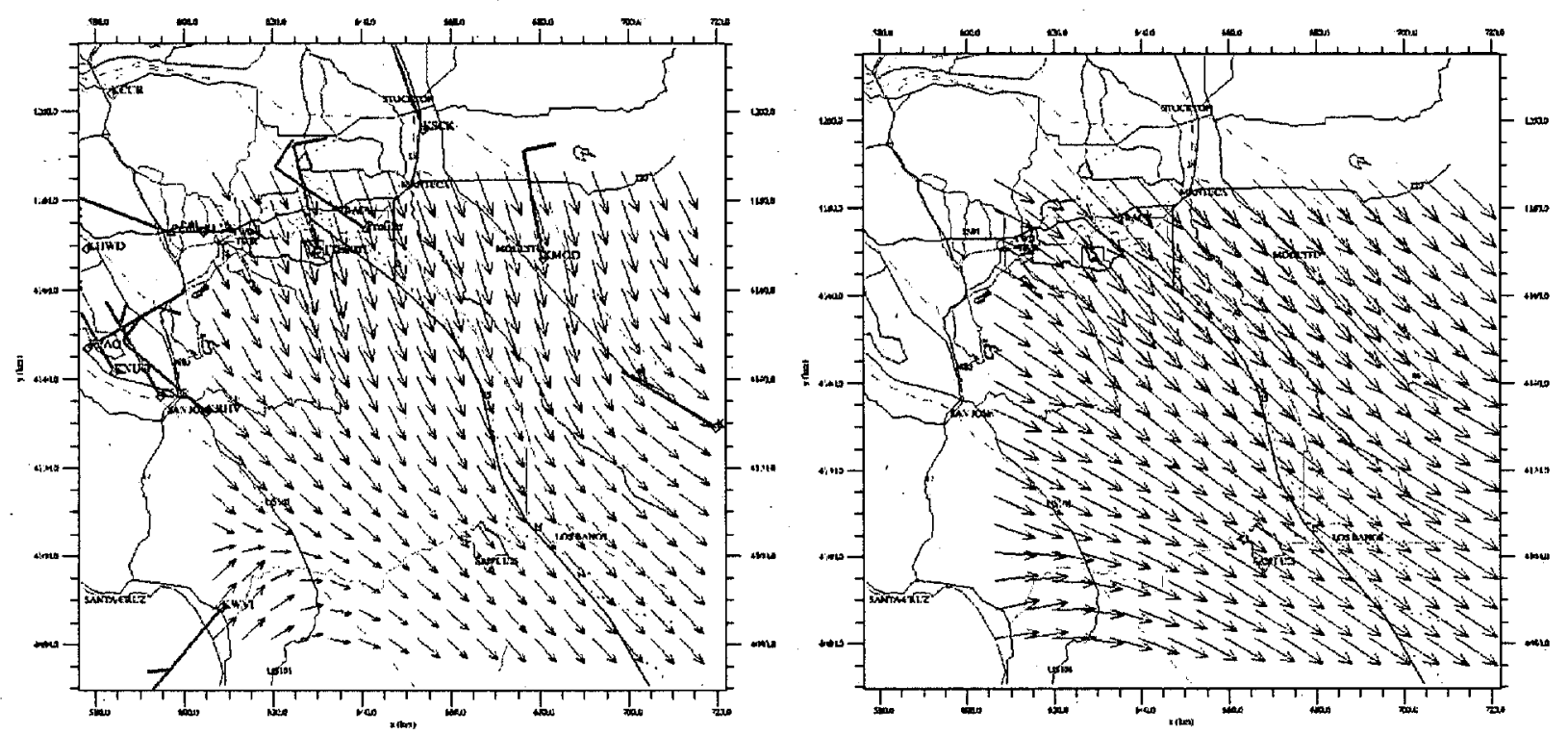

Figure 4. Near-surface wind field (left panel) and mid-level wind field (right panel) from the ADAPT model for 1715 UTC (1015 a.m. PDT) 18 July 2000. These ADAPT wind fields are based on surface, tower, and profiler observations (see text). The purple wind barbs represent the observed winds. 


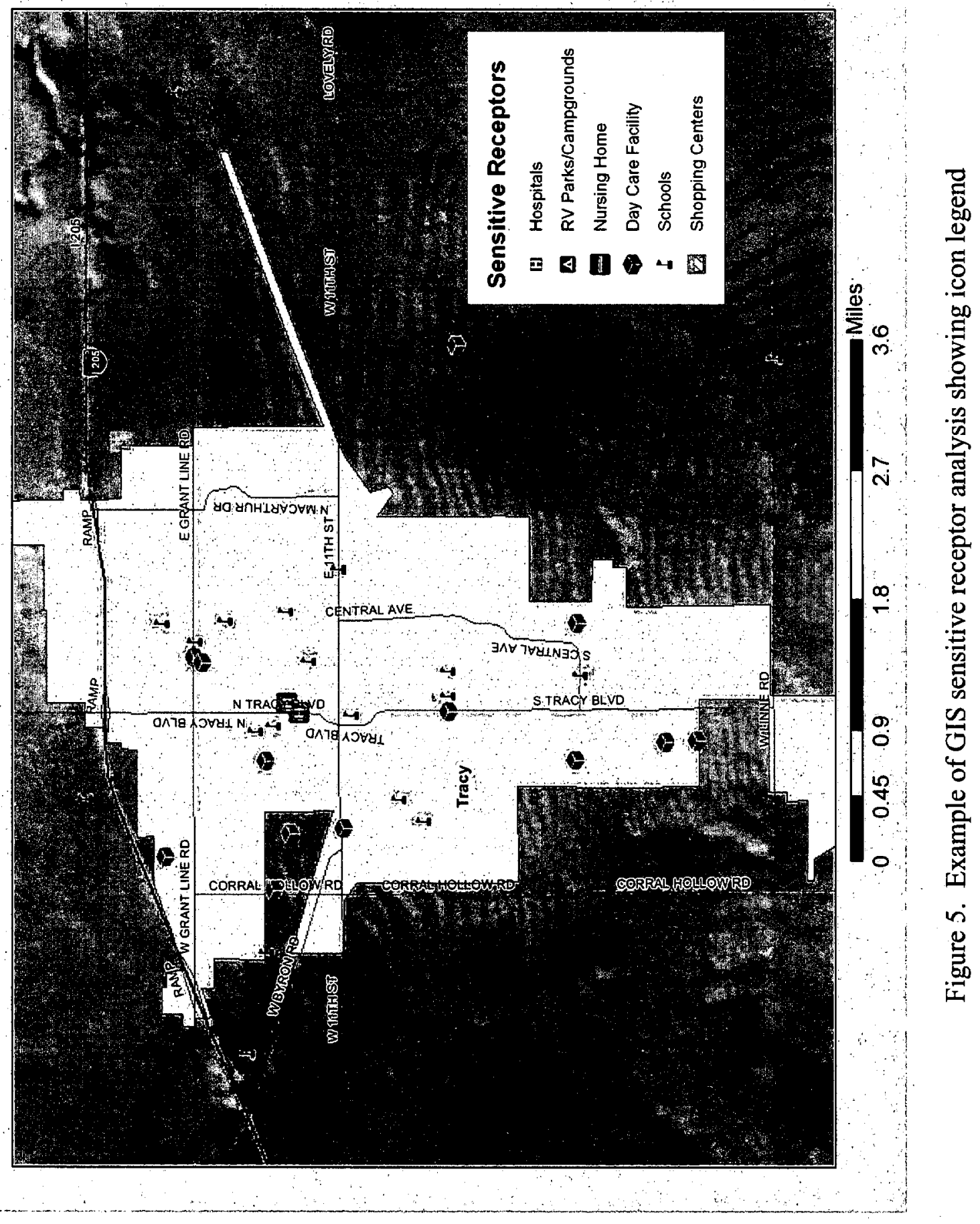




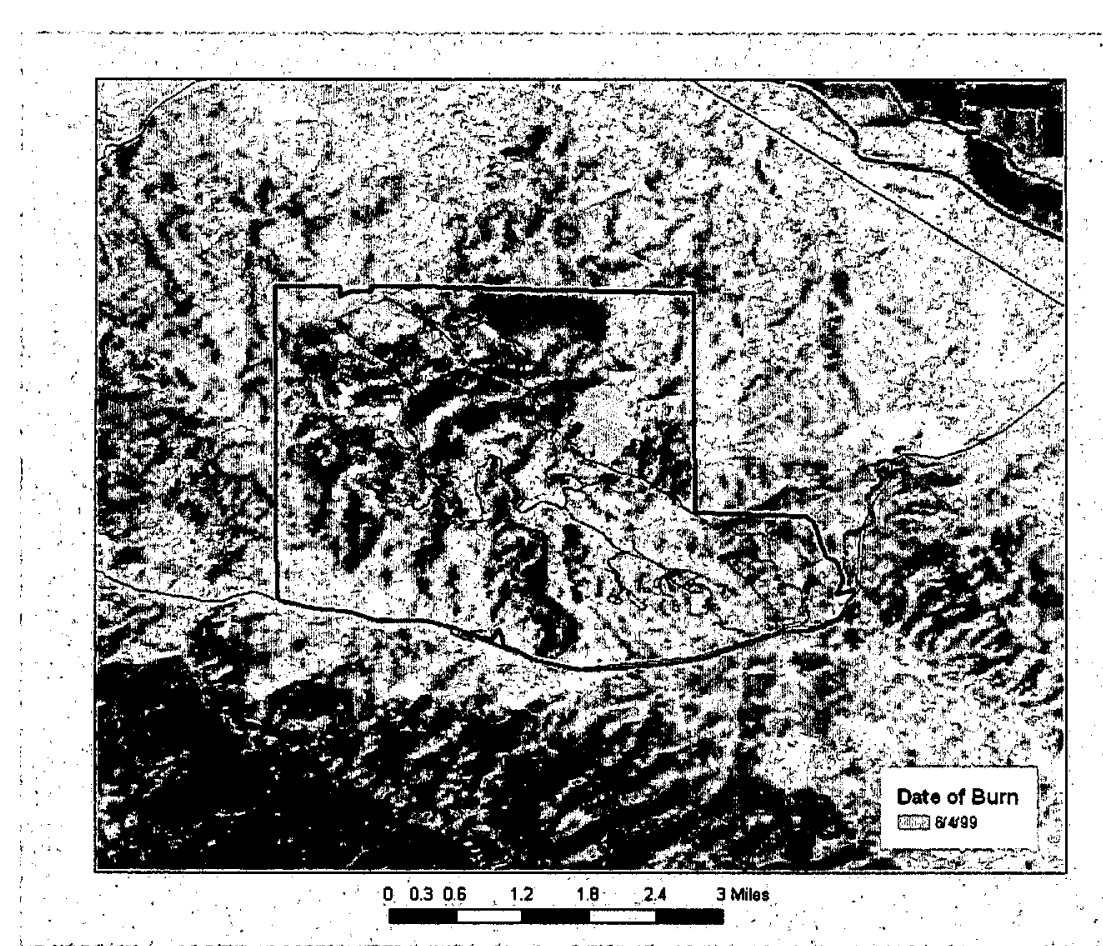

Figure 6a. Prescribed burn plot (yellow area) for June 4, 1999.

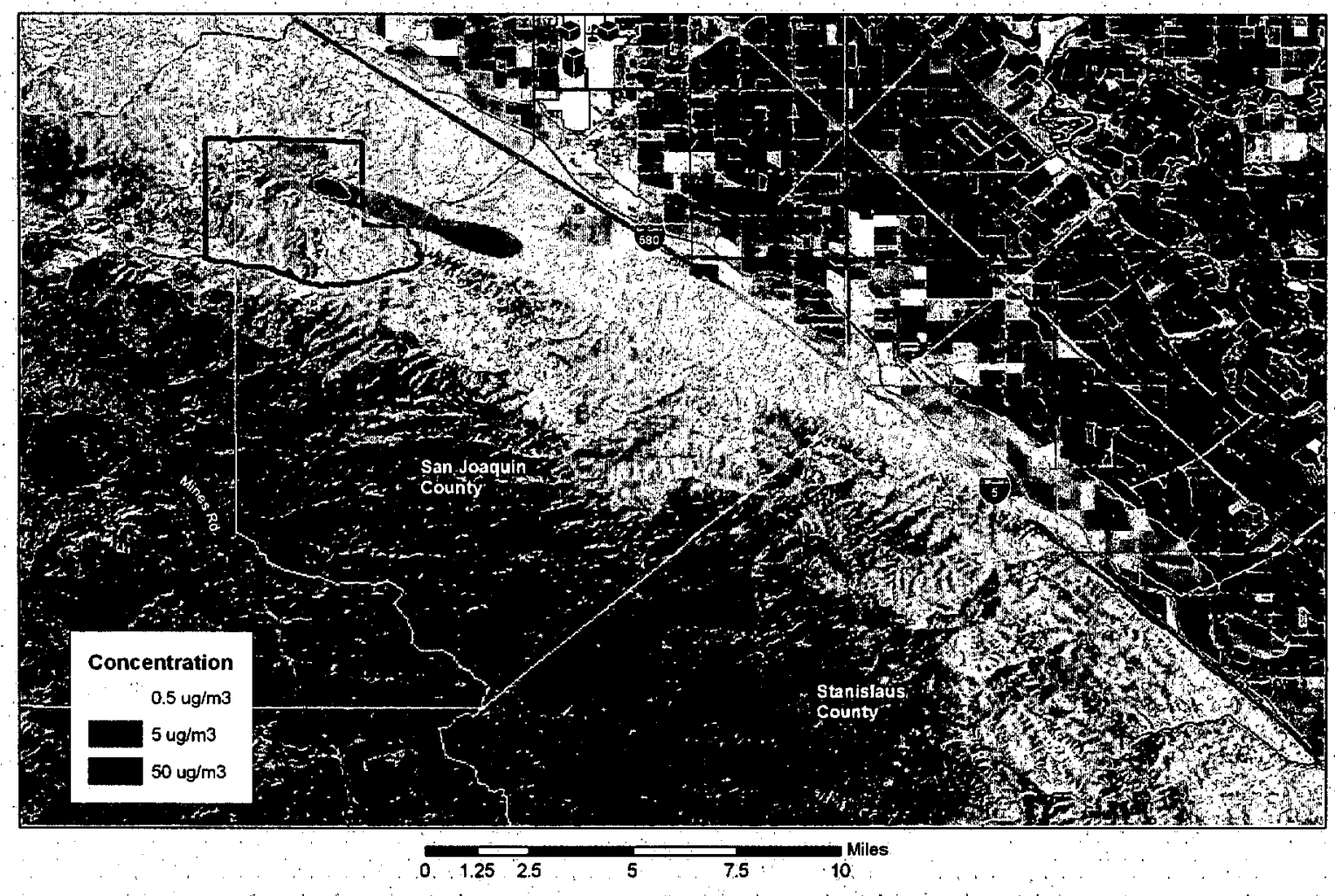

Figure 6b. June 4, 1999 24-hour-average PM10 smoke concentration from the plot 8 burn. 


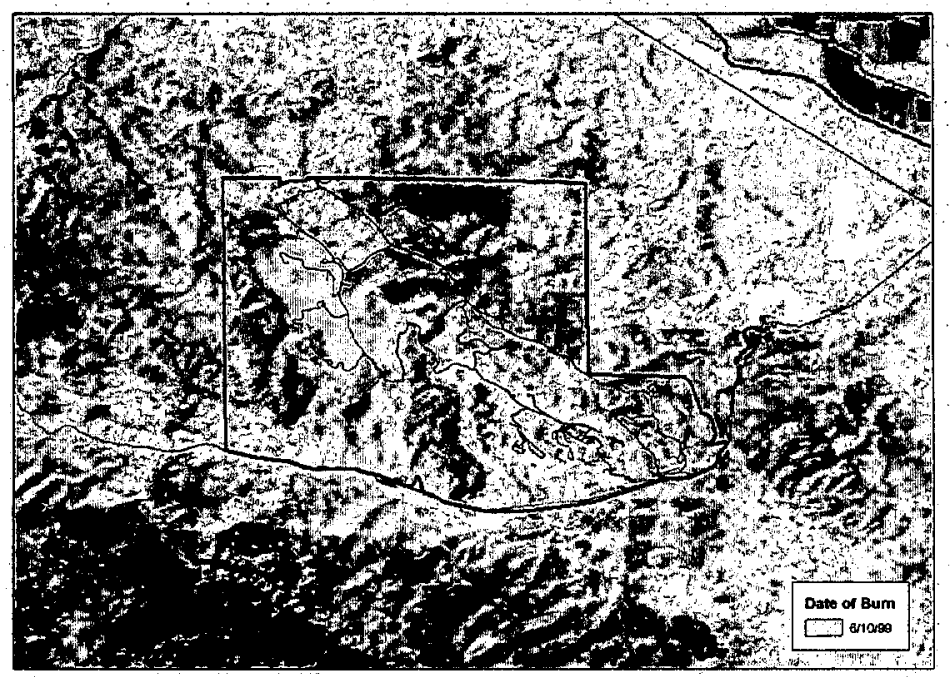

Figure 7a. Prescribed burn areas for June 10, 1999 (three burns).

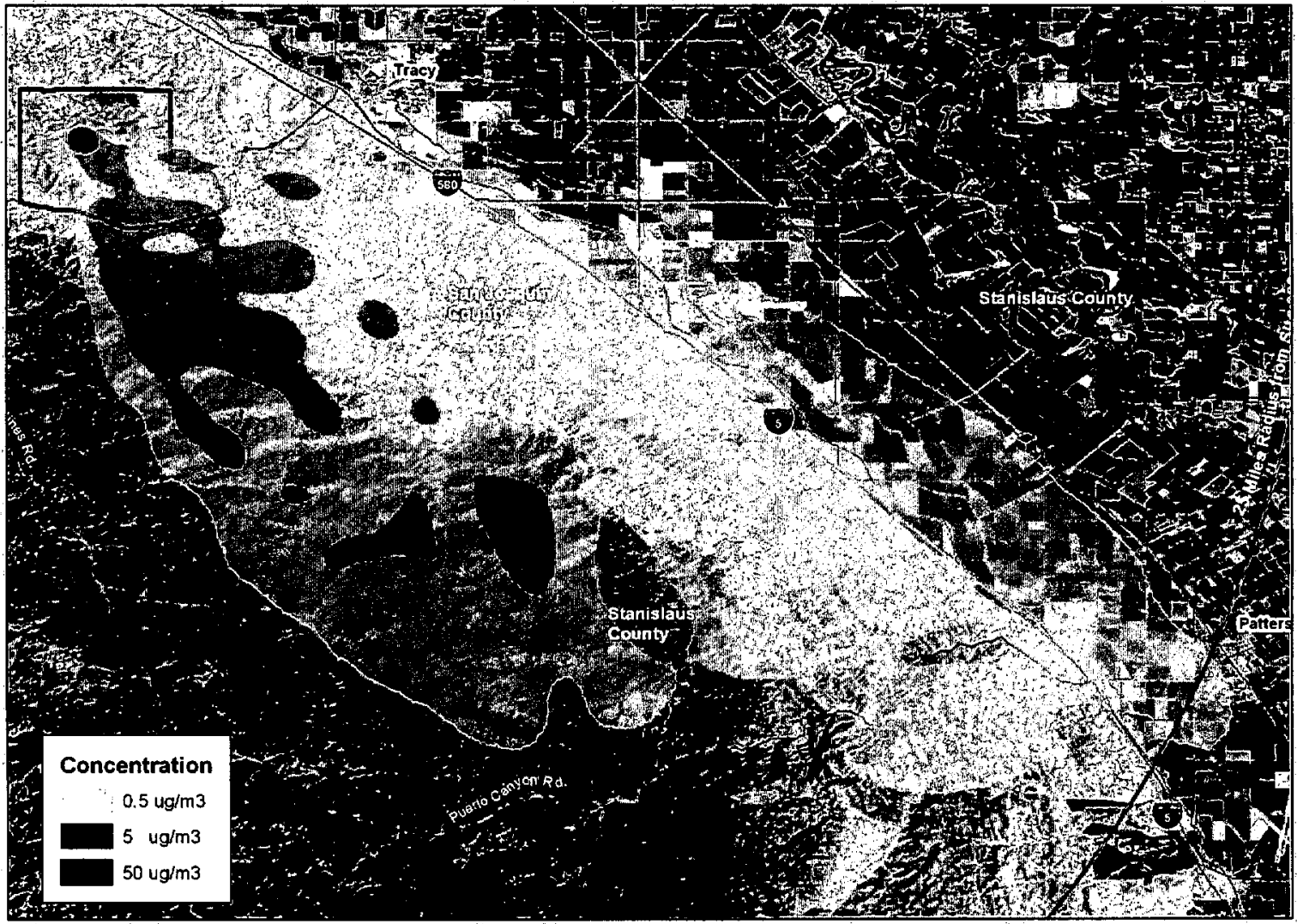

Figure 7b. June 10, 1999 24-hour-average PM10 smoke concentration, summed for all three burns. 


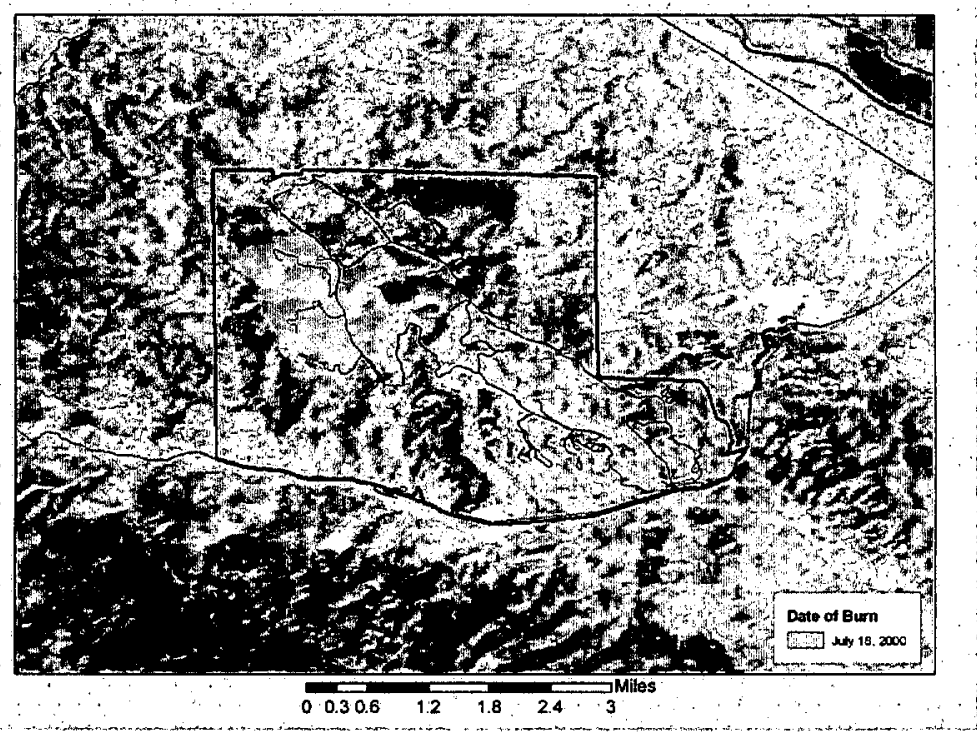

Figure 8a. July 18, 2000 prescribed burn area (three burns).

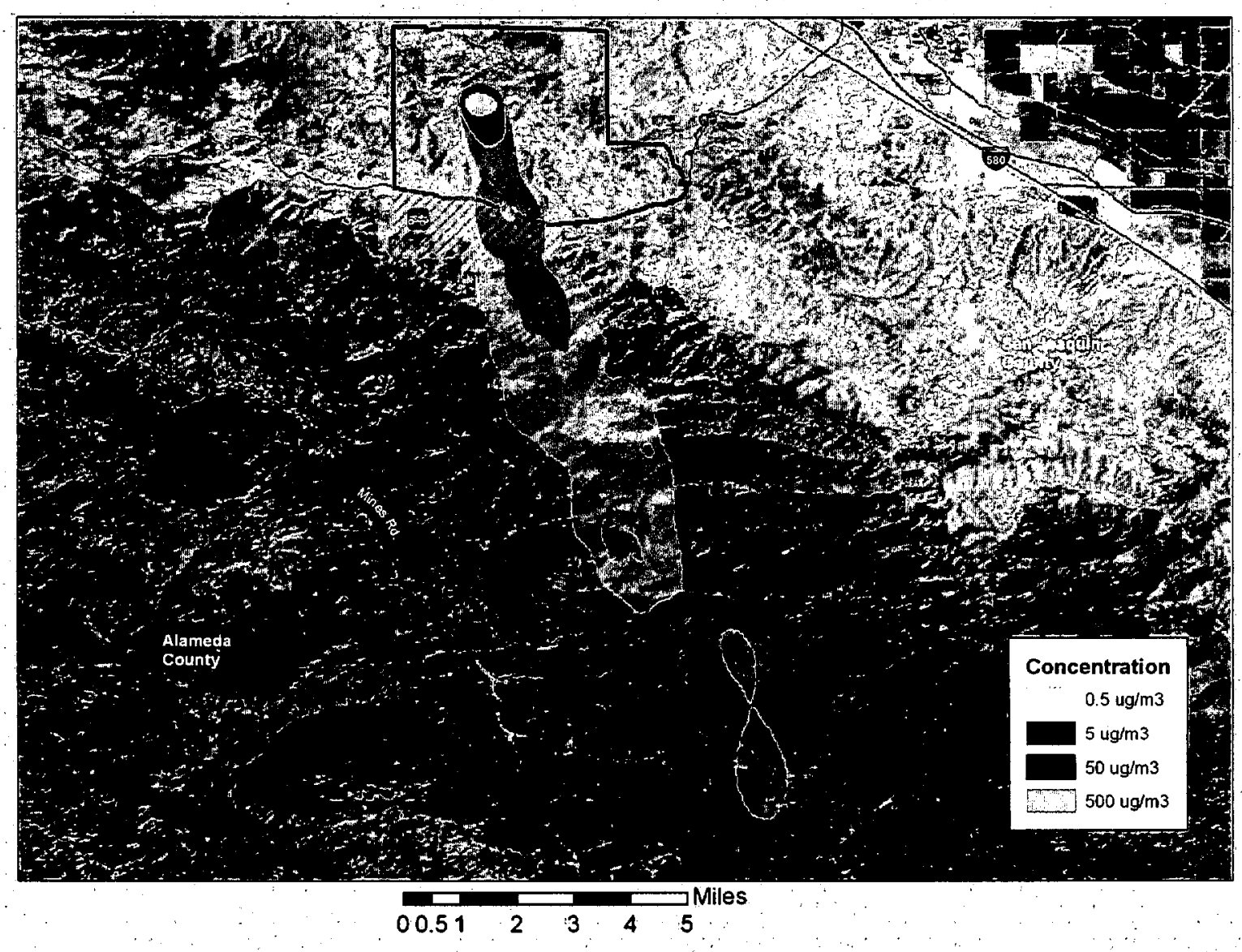

Figure 8 b. July 18, 2000 24-hour-average PM10 smoke concentration, summed for all three burns. 


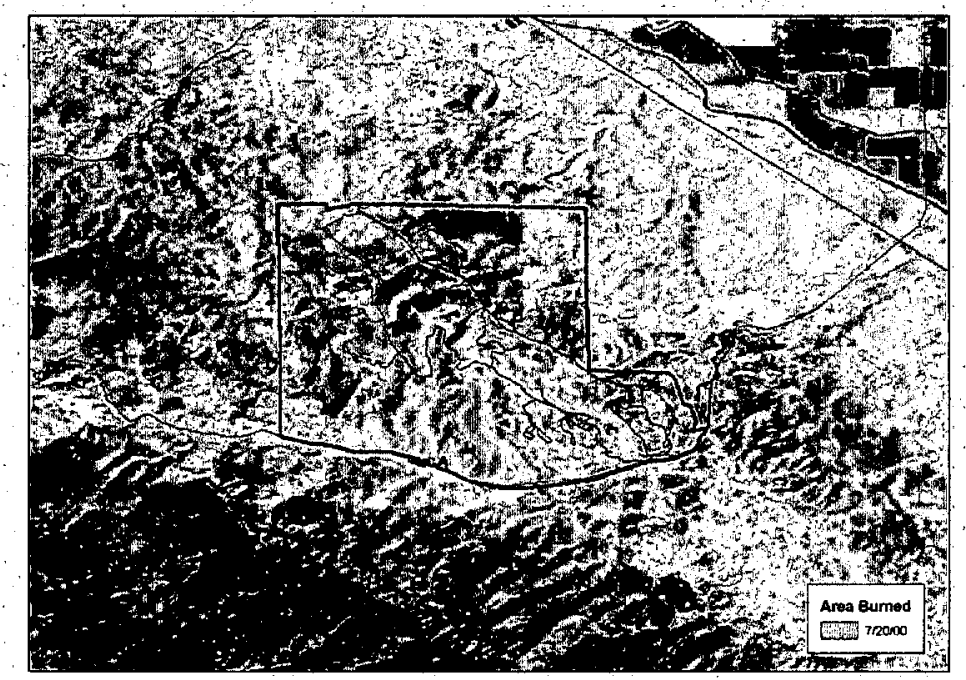

Figure 9a. July 20, 2000 prescribed burn area (one burn).

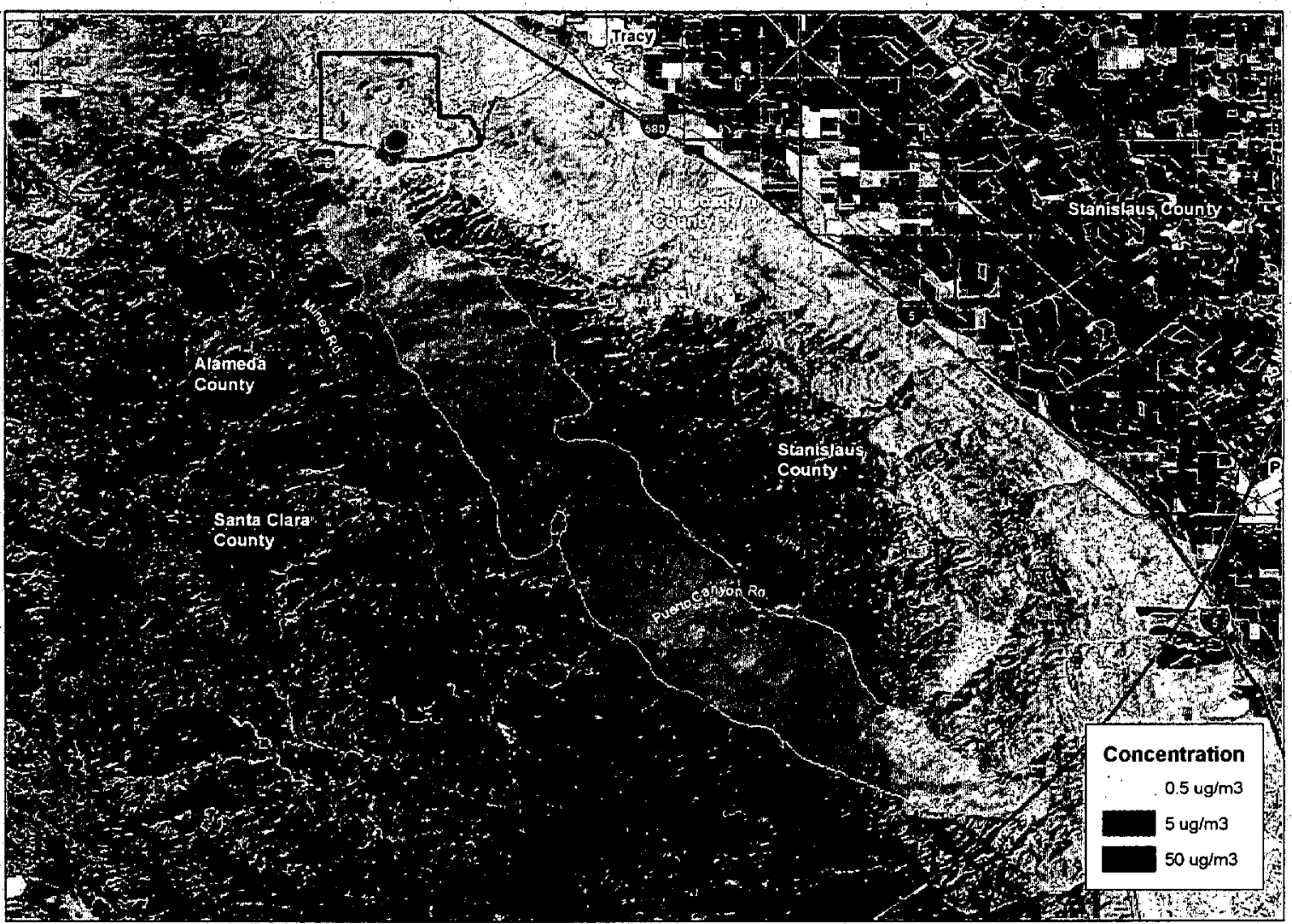

Figure 9b. July 20, 2000 24-hour-average smoke PM10 smoke concentration. 